\title{
Entre a oração e o shopping: anotações sobre a pauta do telejornalismo no natal ${ }^{1}$
}

\author{
Between the prayer and the shopping: notes on the agenda of the broadcasting \\ journalismin the Christmas
}

\section{Entre la oración y el shopping: notas sobre la agenda del periodismo en la televisión durante la Navidad}

\author{
Ana Carolina Rocha Pessoa Temer ${ }^{2}$ \\ Marli dos Santos Santos ${ }^{3}$
}

\section{Resumo}

Este trabalho é parte de uma reflexão continuada sobre Comunicação e Jornalismo, desenvolvida a partir do Laboratório de Leitura Crítica da Mídia, da Faculdade de Comunicação e Informação da UFG, em parceria com o Grupo de Pesquisa Novas Práticas em Jornalismo do Programa de Pós Graduação em Comunicação da Universidade Metodista de São Paulo. O foco da análise são as reportagens transmitidas pela Rede Globo de Televisão durante os meses de dezembro de 2013 e 2014, e o objetivo é apontar as contradições que cercam a cobertura jornalística neste período. A metodologia adotada foi a Análise de conteúdo, tendo como base a classificação de Tuchman e a tipologia de Temer, como fundamento para uma Leitura Crítica do conteúdo midiático. Verificou-se que o agendamento determina o conteúdo da cobertura, confirmando a dependência da pauta do telejornalismo ao previsível, e obedecendo rigorosamente a estética do entretenimento e do serviço, para fins de incentivo ao consumo. A conclusão é que no telejornalismo predomina a ressignificação do Natal como um momento de "comprar, presentear e festejar", com pouco espaço para a religiosidade.

Palavras-Chave: Telejornalismo. Pauta jornalística. Rede Globo de Televisão. Agendamento. Natal.

\section{Abstract}

This work is part of a continuing reflection on the communication and journalism, developed from the Laboratory for Critical Reading of the Media, da Faculdade de Comunicação e Informação da UFG, in

\begin{tabular}{|c|c|}
\hline & cesse este artigo online \\
\hline \multirow{2}{*}{ 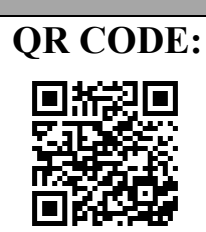 } & $\begin{array}{l}\text { Website: } \\
\text { http://www.revistas.ufg.br/index.php/ci }\end{array}$ \\
\hline & $\begin{array}{l}\text { DOI: } \\
\text { http://dx.doi.org/10.5216/c\&i.v19i1.363 } \\
78\end{array}$ \\
\hline
\end{tabular}
collaboration with the Research Group New Practices in Journalism of the Postgraduate Program in Communication da UniversidadeMetodista de Sao Paulo.The aim of the analysis is the reports transmitted during the months of December of 2013 and 2014, in de Red Globo Television, and de

\footnotetext{
1 Este texto é uma revisão ampliada a partir da inclusão de novos dados e da ampliação da pesquisa de campo, do trabalho intitulado. Entre a oração e o shopping: anotações sobre a pauta do telejornalismo no Natal Brasileiro, que foi apresentado no Grupo de Trabalho GT Estudos sobre Jornalismo, na Alaic/Lima-Peru, em agosto de 2014.

${ }^{2}$ Doutora e Mestre em Comunicação Social pela Universidade Metodista de São Paulo, Especialista em Sociologia pela Universidade Federal de Uberlândia (UFU). Coordenadora do Programa de Pós-graduação em Comunicação pela Faculdade de Informação e Comunicação (FIC) na Universidade Federal de Goiás (UFG). Brasil, Goiás, Goiânia. E-mail: anacarolina.temer@gmail.com.

${ }^{3}$ Doutora em Ciências da Comunicação Universidade de São Paulo. Professora do Programa de Pós-Graduação em Comunicação Social da Universidade Metodista de São Paulo, coordenadora do Grupo de Pesquisa novas Práticas em Jornalismo. Brasil, SP, São Paulo. E-mail: marli.santos@metodista.br.
}

Comun. \& Inf., Goiânia, GO, v. 19, n. 01, p.52-69, jan./jun. 2016 
goal is pointing out the contradictions on the media coverage during this period. The methodology adopted was the contend analysis, based on the Tuchman's classificacion and the typology of Temer for a Critical Reading of Media content. It was found that in the period of Christmas, the agenda determines the content of the coverage, confirming the dependence of the journalistic agenda on television to the predictable, strictly in accordance with the aesthetics of the entertainment and service, with the intention of encouraging consumption. The conclusion is that in the brazilian's journalism on television dominates the resignificance of Christmas as a time of "buy, gifting and hold", with little space for religiosity.

Key Words: Broadcasting Journalism. Agenda. Globo Television Network. Newsmaking. Christmas.

\section{Resumen}

Este trabajo es parte de una continua reflexión sobre la comunicación y el periodismo, desarrollado desde el Laboratorio de Lectura Crítica de los Medios, da Faculdade de Comunicação e Informação da UFG, en colaboración con el Grupo de Investigación Nuevas Prácticas en Periodismo del Programa de Postgrado en Comunicaciónda Universidade Metodista de São Paulo.El objetivo del análisis son los informes transmitidos durante los meses de diciembre de 2013 y 2014, con la intención de señalar las contradicciones en torno a la cobertura periodística durante este período.La metodología adoptada fue análisis de contenido, teniendo como base la clasificación de Tuchman y tipología de Temer, como la base para una lectura crítica de los contenidos de los mediosSe constató que en el periodo de la Navidad, la agenda determina el contenido de la cobertura, confirmando la dependencia dl periodismo en la televisión al previsible, estrictamente de acuerdo con la estética del entretenimiento y servicio, con la intención de alentar el consumo. La conclusión es que en periodismo en la televisión brasileña domina la re significación de la Navidad como un tiempo de "comprar, regalar y celebrar", con poco espacio para la religiosidad.

Palabras-clave: Periodismo en la televisión. Agenda. Red Globo de Televisión. Newsmaking. Navidad.

\section{A CRISE NA AUDIÊNCIA E A CRISE DOS CONTEÚDO}

$$
\begin{aligned}
& \text { segunda década do século XXI estará anotada no telejornalismo brasileiro } \\
& \text { como um período de angústias e questionamentos. Pressionado pela } \\
& \text { disseminação das novas tecnologias, entre elas a multiplicação das }
\end{aligned}
$$

emissoras de sinal codificado (a cabo ou via satélite) e a Internet, as emissoras de televisão abertas enfrentam a queda nos seus índices de audiência. Especialmente no telejornalismo da Rede Globo de Televisão cuja política de investimentos técnicos e acordos com emissoras locais têm garantido uma ampla cobertura (ainda que não equânime) de todo território nacional, a reação à despencada da audiência tem afetado a qualidade do conteúdo.

Apontado historicamente como o principal telejornal do país, o Jornal Nacional fechou 2013 com 26 pontos de média de audiência na Grande SP (MASUTTI, 2013, p. 03), ou seja, a pior média de sua história. Mas este recorde negativo foi superado novamente em março de 2014, quando o telejornal atingiu 18,3 pontos (cada ponto equivale a 65 mil de domicílios na grande São Paulo) ${ }^{4}$. Embora ainda não tenham sido divulgados os números relativos à média

\footnotetext{
4 Jornal Nacional marca pior média de audiência da http://f5.folha.uol.com.br/televisao/2014/04/1439663-jornal-
}

Comun. \& Inf., Goiânia, GO, v. 19, n. 01, p.52-69, jan./jun. 2016 
de audiência de 2014, os dados tornam-se ainda mais graves quando se considera que o Jornal Nacional está "envelhecendo", pois os jovens estão migrando para outras emissoras e outras fontes de informação (TEMER, 2010, p.05).

Para o Jornal Nacional, noticioso da Rede Globo de Televisão que entrou no ar em primeiro de setembro de 1969, e que sempre se pautou pelo objetivo confesso ser a líder de audiência de norte a sul do país, a despencada considerável é um marco doloroso no ano que precedeu ao aniversário de 50 anos de uma emissora que já deteve o virtual monopólio da audiência nacional.

A trajetória da Rede Globo, seus vínculos com o Governo Militar e os caminhos que tomou após o início dos processos de democratização do país, evidentemente, não devem ser esquecidos. Mas em tempos de Internet, Redes Sociais e novas formas de interatividade midiatizada, o questionamento que se impõe é como o modelo tradicional de telejornal irá se adaptar ás diferentes demandas da audiência.

Desta forma, o objetivo deste trabalho é entender o como o telejornalismo da Rede Globo de Televisão vem se comportando no enfrentamento desta crise, buscando se aprofundar nos elementos constitutivos do conteúdo deste telejornalismo, mas também contrapondo dois elementos: as matérias factuais ou duras, que tem elementos característicos das notícias (fatos novos, de interesse público e de interesse do público), com as matérias consideradas mais leves: matérias de serviço e matérias de interesse humano ou ligadas ao consumo. Em função desta proposta foi feita uma Análise de Conteúdo das matérias sobre o Natal, consumo e questões relativas religiosidade e as festas de final de ano veiculadas pelo telejornalismo nacional da Rede Globo de Televisão (Bom Dia Brasil, Jornal Hoje, Jornal Nacional e Jornal da Globo), tendo como base, e a classificação por tipo de conteúdo de Temer (2002).

Entende-se como Análise de Conteúdo o método de trabalho científico e uma Técnica de investigação em geral vinculada ao positivismo comteano ${ }^{5}$ e cuja origem documentada remonta ao final do século XIII ${ }^{6}$. O método está presente desde os primeiros trabalhos de communication reserach, tendo passado por ciclos de grande reconhecimento (como no período da segunda guerra mundial) e de fases marcadas por críticas severas (como na década de 1970),

nacional-marca-pior-media-de-audiencia-de-sua-historia-na-previa.shtml. Acesso em 19 de maio de 2015.

${ }^{5}$ Corrente de pensamento desenvolvida por Augusto Comte, O positivismo valoriza as ciências exatas como paradigma de cientificidade e como referência do espírito humano em seu estágio mais elevado (FONSECA JÚNIOR, 2006, p. 281)

${ }^{6} \mathrm{O}$ primeiro trabalho de Análise de Conteúdo é atribuído a uma procura sistemática pelos membros da corte suíça na análise de 90 hinos religiosos anônimos, denominados Os cantos do Sião em busca de provas de heresia. (FONSECA JÚNIOR, 2006, p. 280).

Comun. \& Inf., Goiânia, GO, v. 19, n. 01, p.52-69, jan./jun. 2016 
em geral elaboradas por pesquisadores com base marxista em função de seus vínculos com a tradição positivista. Essas críticas tem sido superadas, no entanto, pelos autores modernos que, mesmo, assim como está sendo feito nesta pesquisa, se pautam pela noção de que "o trabalho crítico não se define pelas técnicas que utiliza” (LOZANO, 1994).

Para a análise considerou-se o material veiculado nos meses de dezembro de 2013 e 2014, analisado a partir da tipologia do material jornalístico (TEMER, 2002, p. 195), na qual é reforçada a relação entre o conteúdo factual (notícia) e o material jornalístico de serviço, mas também a classificação didática elaborada por Tuchman ( PENA, 2005), além de considerações sobre os vínculos destes conteúdos com outras mídias, em particular o emissora de sinal codificado Globo News e os portais da Rede Globo de Televisão. A análise foi centrada especialmente em uma Leitura Crítica, buscando apontar os aspectos específicos da cobertura das festas natalinas e/ou relativas a religiosidade.

\section{SOBRE A TELEVISÃO, RELIGIOSIDADE E O NATAL}

A televisão brasileira nasceu a partir da iniciativa privada do empresário Assis Chateaubriand, sem ligação aparente com o Estado e a religião. Essa simplicidade, no entanto, esconde ambiguidades, como a presença de Frei José de Jesus Mojica, ex-ator/galã do cinema mexicano, que teria cantado um bolero romântico na primeira transmissão da televisão, no dia 4 de julho de 1950 - a data oficial da estreia é 18 de setembro de $1950^{7}$.

Desde então essa vem se perpetuando na programação televisiva a transmissão de missas dominicais e cerimônias religiosas, especificamente as católicas. A fé também estava representada nos conteúdos ficcionais, nos finais felizes das novelas,normalmente coroados por cerimônias de casamento em igrejas católicas, ou por personagens representando padres e religiosos com participação importante nas tramas. Particularmente no telejornalismo da Rede Globo de Televisão, o acompanhamento/cobertura de festas de caráter religioso e cerimônias religiosas ocorrem regularmente - novamente com predominância da religião Católica. $\mathrm{Na}$ televisão brasileira do século XXI essa relação assumiu neste século um caráter de "resistência", com o crescimento e consolidação da Rede Record, ligada à Igreja Universal do Reino de Deus, que se tornou a sua principal concorrente. Evidentemente, a emissora está ciente do crescimento deste público, e está também investindo na cobertura de eventos como a "Marcha para Jesus"8,

\footnotetext{
${ }^{7}$ Há outrasreferênciaspara a data desta transmissão, como o dia 3 de abril, conforme site da Rede Tupi. Neste trabalho optou-se pela referência citada pelo Jornal O Estado de S. Paulo, 2000

${ }^{8}$ No caso específico, liderada pela igreja Renascer em Cristo.
}

Comun. \& Inf., Goiânia, GO, v. 19, n. 01, p.52-69, jan./jun. 2016 
que tem reunido milhares de seguidores, especialmente jovens das grandes cidades brasileiras, como São Paulo9.

Dentre as festas religiosas que têm maior destaque, o Natal é uma das mais significativas das religiões cristãs, uma vez que celebra o nascimento de Jesus Cristo, a figura central do Cristianismo. Justamente em função de sua importância a verdade é que, embora a data tenha sido estipulada no ano de 350 em 25 de dezembro ${ }^{10}$ pelo Papa Júlio I, chefe da Igreja Católica Romana, sua importância ultrapassa o catolicismo romano, e é referência para diferentes religiões cristãs. De fato, embora as comemorações religiosas tenham atravessado séculos, elas foram constantemente apreendidas ou reinterpretadas de diferentes formas, ou por meio de diferentes simbologias. Essa questão toma novo fôlego na contemporaneidade já que, de acordo com Ianni, citado por Melo (1998, p. 33), na sociedade globalizada as "religiões e seitas (...) ressurgem como se fosse erupções vulcânicas. Mas ressurgem diferentes, com outros significados, com outros horizontes".

Embora ainda exista um discurso sobre solidariedade, religiosidade e eventualmente assistencialismo, o Natal está cada vez mais vinculado a noção de festas, decoração, compras e presentes. Segundo uma pesquisa realizada pelo Instituto de Cultura e Mídia do Centro de Pesquisa de Mídia (CMI), organismo de vigilância da mídia conservadora norte americana, apenas 1,3\% das histórias no "World News" da ABC, "CBS Evening News" e "NBC NightlyNews" das redes ABC, CBS e NBC, mencionaram Jesus ou seu nascimento durante seus telejornais da noite. Das 527 histórias sobre o Natal, Deus ou o nascimento de Jesus Cristo foram mencionados em apenas sete ${ }^{11}$.

Neste contexto, a análise busca compreender até que ponto, na cobertura telejornalística nacional, o Natal se vinculou à ideia de troca de presentes, um (hábito que originalmente tem referência à visita dos reis magos ao Jesus recém-nascido) e está se afastando de significados mais ligados a aspectos religiosos. A questão torna-se ainda mais relevante quando comparada à cobertura mais ampla do telejornalismo, uma vez que no Brasil o período de Natal é marcado também pelo encerramento do ano letivo, festas de formatura, viagens de férias e pelos extremos climáticos característicos do verão brasileiro, que em geral são agentes de tragédias (desabamentos, acidentes de carros, e muitos outros). Nos dois períodos

\footnotetext{
${ }^{9}$ A Marcha realizada em São Paulo reuniu milhares de pessoas no feriado de Corpus Christi, de 04 de junho de 2015, liderada pela igreja Renascer em Cristo "em defesa da união das diferentes denominações evangélicas em torno da crença em Jesus Cristo.” (G1, 2015).

${ }^{10}$ Data geralmente vinculada a festa pagã conhecida como Saturnália.

${ }^{11}$ Pesquisa mostra que mídia mal fala de Jesus na cobertura do Natal.(Folha Gospel, 2010).
}

Comun. \& Inf., Goiânia, GO, v. 19, n. 01, p.52-69, jan./jun. 2016 
investigados, dezembro de 2013 e 2014, esses extremos se expressaram pelas enchentes no Estado do Espírito Santo e pela estiagem prolongada no sudeste (e particularmente em São Paulo), com a redução dramática das de água em reservatórios ${ }^{12}$.

\section{JORNALISMO: NATUREZA E COMPROMISSOS}

Em termos gerais, jornalismo é a atividade informativa, periodicamente difundida através dos veículos de comunicação com alto grau de reprodutibilidade (rádio, televisão, revista, internet) cujo conjunto vulgarmente chamamos de imprensa. Em termos mais específicos o jornalismo é uma ação (conjunto de ações) de comunicação característico da sociedade capitalista-industrial, que se impõe como modelo institucionalizado de transmissão de informações verdadeiras, de interesse público e de interesse do público, a partir das democracias republicanas formatadas em função de um modelo burguês e urbano. Em decorrência dessas características, o jornalismo é uma atividade diretamente ligada à busca da verdade- elemento essencial ao jornalismo - ao questionamento das autoridades e à essência do progresso (MARCONDES FILHO, 2000, p. 9).

Estes elementos, em si mesmo complexos, se definem a partir da compreensão de alguns conceitos básicos, e embora não seja possível esgotá-los neste texto, é importante entende-los a partir do sentido de ação e do conceito de capitalismo industrial.

Weber (1972, p. 15) situa a noção de ação em termos sofisticados, entendendo-a como um movimento contínuo, cujas consequências podem potencialmente ultrapassar a ação em si, gerando impactos na vida social e novas ações. Groth (2011), discípulo de Weber, insere a essa percepção a noção de que o ser humano está envolvido em um mundo objetivo, delimitado pela natureza, sociedade e cultura, com o qual se relaciona - age sobre e ao mesmo tempo é sujeito de suas ações - em um movimento de contínua ação e reação. Ações de comunicação, portanto, aceleram essas relações uma vez que diferem das demais ações por ser uma ação sobre o(s) outro(s) indivíduo(s) (que domina um mesmo código e é igual em potencial de compreensão).

Inseridos em uma dinâmica do capitalismo-industrial, que combina “...um sistema de produção de mercadorias centrado sobre a relação entre a propriedade privada do capital e o trabalho assalariado sem posse da propriedade" com o "...uso de fontes inanimadas de energia material para a produção de bens, combinado a papel central da maquinaria no processo de

\footnotetext{
12 Apesar de terem ocorridos também algumas chuvas mais fortes em algumas regiões no período mais próximo ao Natal.
}

Comun. \& Inf., Goiânia, GO, v. 19, n. 01, p.52-69, jan./jun. 2016 
produção"13 (GIDDENS, 1991, p.61), as condições sociais e o desenvolvimento técnico e tecnológico - que em si mesmo representam propostas humanas de redimensionar a relação espaço-tempo, e consequentemente, as relações com a sociedade e a natureza - o discurso jornalístico potencializa os efeitos da comunicação, e deve ser compreendido como uma ação social (CHAPARRO, 1994, p. 13) que se torna uma mediação que afeta em larga escala a vida social.

Para Chaparro (1994), a ação jornalística fundamenta-se na tríade formada pela ética, técnica e estética que se diferencia de outros conteúdos formalizando compromisso na divulgação de fatos verdadeiros. A verdade existe no jornalismo como meta desejada, e mesmo que os limites impostos pela linguagem e pelas representações sígnicas tornem a divulgação da verdade algo intrinsecamente impossível, o seu inverso - a mentira, a fantasia, a invenção constituem-se a negação da função definidora do próprio jornalismo. Neste contexto é necessário entender que as empresas jornalísticas - e por extensão o jornalismo - não devem ser vistas apenas como “...empresas capitalistas com a ânsia do lucro, mas também organizações políticas que funcionam como clubes políticos” (WEBER, 1972, p.80-81).

Enquanto conteúdo o jornalismo é delimitado também pelo que Groth (2011), ao desenvolver os estudos sobre as bases da "jornalística", define como pilares da atividade: a atualidade, a difusão pública, a universalidade e a periodicidade. Além disso, no decorrer do seu desenvolvimento o jornalismo incorporou também um status de um serviço ao público, uma vez que informa sobre os elementos essenciais a vida diária, dá visibilidade ao Estado e as ações e decisões que afetam a sociedade, ainda que não seja necessariamente ser um serviço público, no sentido restrito de serviço essencial subsidiado pelo Estado.

Mas trata-se de uma relação marcada por tensões internas, uma vez que o jornalismo se consolidou principalmente a partir de empresas privadas, voltadas para o lucro, em um modelo marcado pelo capitalismo e pela valorização utópica de ideias de liberdade de opinião e expressão. Considerando estes aspectos, compreende-se que a imprensa capitalista é um mecanismo complexo, que ao mesmo tempo em que expõe que tem como princípio ético a busca da verdade e o compromisso com a pluralidade de opiniões, também controla tanto a exposição da verdade por meio da divulgação de versões comercialmente ou estrategicamente "mais interessantes".

\footnotetext{
${ }^{13}$ A conceituação de capitalismo industrial está centrada na somatória das definições de Giddens sobre Capitalismo e Industrialismo, ambas citadas no texto. (GIDDENS, 1991, p. 61)
}

Comun. \& Inf., Goiânia, GO, v. 19, n. 01, p.52-69, jan./jun. 2016 
Estudar jornalismo, portanto, é compreender a complexidade das relações - inclusive as relações de poder - na sociedade contemporânea. Para entender como estes elementos se articulam, é necessário levar em consideração nas análises as perguntas propostas por Chaparro (1994): “a) Como se manifestam os propósitos que motivam as intenções que controlam as mensagens jornalísticas; b) que interesses estão conectados a tais propósitos e princípios éticos que inspiram e, c) que influencia a explicitação das intenções exerce no leitor"

\section{SOBRE O TELEJORNALISMO}

Uma vez que o telejornalismo é a caracterização do jornalismo para a televisão, ou na televisão, sua prática respeita (ou deveria respeitar) os princípios básicos que definem o jornalismo. Neste sentido, para entender os telejornais, é necessário considerar os elementos definidos como as delimitações da ética jornalística, mas sem minimizar as técnicas, sociais e econômicas que determinam sua produção, entre elas a necessidade econômica e estratégica de conquistar/seduzir o público numericamente expressivo ou, traduzindo em termos práticos: para os telejornalistas (e para as empresas jornalísticas) "Não adianta fazer o melhor telejornal do mundo se ninguém for vê-lo" (TEMER, 2002, p. 235) ${ }^{14}$.

Considerado estes aspectos, entende-se também que o telejornalismo é, por princípio, o espaço da informação verdadeira (ou da não ficção) na televisão. No entanto, a produção telejornalística está ordinariamente vinculada a empresas midiáticas de grande porte, com envolvimento na produção de diferentes tipos de conteúdos. Esses elementos fazem da televisão um veículo que prioriza conteúdos emocionais, que veicula diferentes materiais sempre convidando para a dramatização (BOURDIEU, 1997, p.71). Portanto, o telejornalismo é permanentemente contaminado pelo sincretismo ${ }^{15}$, e um emaranhado de tensões cuja tendência é diluir as fronteiras entre o real e as representações "coloridas" ou espetacularizadas.

Além disso, ainda que o telejornal seja um gênero facilmente reconhecido no conjunto da programação histórica, com uma formatação bastante definida, trata-se também de um produto caro, uma produção que exige investimentos em recursos e em mão de obra, e uma organização produtiva sofisticada. Em grande parte, isso ocorre porque, a exemplo de outros

\footnotetext{
${ }^{14}$ A autora destaca que a frase não é uma representação literal, mas a tradução de um pensamento recorrente entre os jornalistas da Rede Globo contatados/entrevistados durante a pesquisa que deu origem ao livro.

15 Entendendo sincretismo como uma "... tendência para homogeneizar a diversidade dos conteúdos da comunicação de massa (principalmente a informação e a ficção), a contaminação entre o real e o imaginário. $\mathrm{O}$ real toma a aparência de ficção e a ficção toma a aparência do real, se confundindo na realidade do receptor." (TEMER \& TONDATO, 2009, p.5).
}

Comun. \& Inf., Goiânia, GO, v. 19, n. 01, p.52-69, jan./jun. 2016 
veículos, como o rádio, a televisão é dependente da instantaneidade, da permanente exploração e da transmissão ao vivo ou que pelo menos pareça ser ao vivo. Essa característica envolve a posse simbólica da tecnologia e o domínio das técnicas do jornalismo e, portanto, tem um valor simbólico de competência, agregando maior credibilidade ao material veiculado. Esta característica define sua organização interna, e é repassada ao telespectador como uma marca de qualidade.

Em termos de excelência, idealmente o telejornalismo deveria ser totalmente transmitido ao vivo, mas o que existe efetivamente é uma apresentação ao vivo, um anúncio feito ao vivo por noticiaristas e/ou editores - âncoras de um conjunto de conteúdos (matérias jornalísticas) que inclui material pré-gravado e algumas (poucas) transmissões ao vivo. A dificuldade de uma produção ao vivo não reside apenas nas questões técnicas/tecnológicas ou financeiras. $\mathrm{O}$ jornalismo trabalha com uma matéria prima essencialmente inconstante e de qualidade irregular. Os fatos não acontecem apenas no horário em que o telejornal vai ao ar, e para entendê-los é quase sempre é necessário "voltar no tempo" e apresentar o seu desenvolvimento.

Uma das regras do telejornalismo, portanto, é produzir matérias jornalísticas diferenciadas, conteúdos de serviço ou de interesse humano, que possam ser usadas nos dias em que as notícias não sejam tão impactantes. No entanto, uma das regras da empresa capitalista (e não só das empresas jornalísticas, mas também destas empresas) é o não desperdício da mão de obra e dos recursos de uma forma geral. No telejornalismo isso significa que, uma vez produzido, tem que ser veiculado.

Desta forma, um dos primeiros movimentos do jornalismo é hierarquizar o fato, colocá-lo em um escala de valores que defina comparativamente se os receptores devem "tomar conhecimento" daquele fato. A hierarquização dos fatos/acontecimentos acontece a partir de diferentes critérios. Em uma classificação didática na Tabela 1, Tuchman (2002), qualifica o material jornalístico em matérias podem ser duras e leves, sendo as primeiras subdivididas em súbitas, em desenvolvimento ou em sequência, e em leves. 
Tabela 1 - Tipificação das matérias, segundo Tuchman (2002)

$\begin{array}{ll}\begin{array}{l}\text { Duras ou } \\ \text { Factuais }\end{array} & \begin{array}{l}\text { Súbitas: sem previsão - ex.: tragédias, incêndios, } \\ \text { acidentesEm desenvolvimento. Acontecimentos que geram } \\ \text { fatos - ex: resgate dos feridos após um acidente. }\end{array} \\ \text { Em sequência } & \begin{array}{l}\text { Fatos pré-programados - ex.: desenvolvimento de um } \\ \text { campeonato, votação de uma nova lei, cobertura de um } \\ \text { julgamento. }\end{array} \\ \text { Leves } & \begin{array}{l}\text { Não perdem atualidade - ex.: jogos, exposições, } \\ \text { inaugurações, etc. }\end{array}\end{array}$

Fonte: Pena, 2005.

A partir do primeiro movimento de seleção: a separação dos fatos (ordinários) dos fatos não ordinários, ou seja, fatos que vão além do imediato, e, portanto, estão no topo desta hierarquia são definidos principalmente em função de sua imprevisibilidade dentro do sistema, mas também pela aplicação geral dos critérios dos valores notícia.

Ainda que pareçam óbvias e se "imponham" aos jornalistas e à imprensa, as notícias são produtos formatados pelas condições do presente - pelas determinações sociais, políticas, culturais e tecno-tecnológicas do momento no qual acontecem. Dessa forma no período do Natal, certos temas - como o consumo, o assistencialismo, a religiosidade, a solidariedade, etc - ganham uma dimensão maior do que teriam no restante do ano.

Em termos de serviço, o servicejournalism ${ }^{16}$, termo originalmente utilizado nos Estados Unidos (DIEZHANDINO, 1994, p.75), as matérias jornalísticas possuem diferentes formatos, mas o que as distingue é “...a intenção de esclarecer, orientar ou mesmo despertar a consciência do telespectador quanto a um problema qualquer. (REZENDE, 1997, p.168). Eide (1997) chama de "jornalismo de serviço" o jornalismo cuja que pretende servir de guia aos leitores, prepara-los para agir como consumidores racionais de produtos, serviços e direitos sociais

Mas o Natal é também um período diferenciado no que se refere à necessidade de serviços. Entre as compras e as viagens de final de ano, dar receitas para a ceia de Natal e muitas outras ações práticas, o jornalismo tende a oferecer para o seu receptor uma quantidade considerável de matérias agendadas, e principalmente, matérias de serviços.

A confrontação do material de serviço e outras matérias agendadas com a cobertura jornalística das questões factuais, e em particular as tragédia ou extremos climáticos, oferece

\footnotetext{
${ }^{16}$ A expressão fixou um significado diferenciado que se caracteriza por matérias cuja a intenção é “.... esclarecer, orientar ou mesmo despertar a consciência do telespectador quanto a um problema qualquer.” (REZENDE, 1997, p.168). O“jornalismo de serviço" pretende servir de guia aos leitores, preparando-os para agir como consumidores racionais de produtos, serviços e direitos sociais (EIDE, 1997, p.173-182).
}

Comun. \& Inf., Goiânia, GO, v. 19, n. 01, p.52-69, jan./jun. 2016 
uma situação limite que permite entender de forma mais aprofundada algumas características específicas sobre o jornalismo.

\section{REVENDO OS TELEJORNAIS DE DEZEMBRO DE 2013 E 2014: ASPECTOS} GERAIS

O telejornalismo da Rede Globo de Televisão, e em particular nos telejornais da emissora exibidos nacionalmente (Bom Dia Brasil, Jornal Hoje, Jornal Nacional e Jornal da Globo) teve (e ainda tem) grande influência no conjunto do telejornalismo brasileiro. De muitas formas trata-se de um modelo tradicional, ancorado em uma tradição que envolve o uso sofisticado de aparatos tecnológicos e da valorização da estética, na qual existem poucos espaços para improvisação e para exibição de material com características especiais (ou seja, autorais).

Neste modelo de telejornalismo, a informação flui em camadas sobrepostas, com a diluição da imagem na tela em elementos diferentes, mas com um conteúdo redundante: a imagem principal, do fato ou do noticiarista narrando o fato, e imagens secundárias - o textolegenda da própria notícia, o crédito dos repórteres e dos entrevistados, as vinhetas. Também o som é diluído, a narração se sobrepondo ao som de fundo, ao background sonoro que remete ao local do onde o fato aconteceu, e outras interferências sonoras eventuais. Em função destas características, o telejornalismo envolve o trabalho de diferentes profissionais atuando como filtros e de forma paralela e/ou em conjunto, quase sempre em que o ritmo de produção acelerado.

Este conteúdo é organizado em blocos, nos quais predomina claramente o gênero reportagem, com espaço menor para outros formatos. De uma forma geral, não existe uma separação formal entre os assuntos ou editorias, ou mesmo entre a cobertura de diferentes localidades, embora exista uma tendência para agregar assuntos próximos ou semelhantes. O material é constantemente identificado por legendas ou vinhetas, que reafirmam informações já presentes no texto. A organização interna dos telejornais segue um esquema rígido, no qual o noticiarista/apresentador introduz o repórter, que por sua vez "abre espaço" para os entrevistados, evidenciando o nível hierárquico de cada um deles dentro do telejornal. Neste modelo cada participante tem um papel determinado, cuja importância fica evidente pelo tom de voz e pela expressão facial adotada pelo seu enunciador. Os diferentes status dos diferentes conteúdos transpiram a partir destes elementos e, de forma sub-reptícia, permitem ao telespectador entender qual é o momento certo para lamentar ou para sorrir.

Comun. \& Inf., Goiânia, GO, v. 19, n. 01, p.52-69, jan./jun. 2016 


\section{REVENDO CRITICAMENTE OS TELEJORNAIS DA REDE GLOBO}

A amostra dos dados para o tema proposto, a cobertura sobre o Natal, teve como foco as matérias veiculadas de 01 a 30 de dezembro de 2013 e 2014, período em que há mais referências ao tema em razão da proximidade do Natal. Assim, por meio das palavras-chave "Natal", "Dezembro de 2014”, “Jornal Nacional”, "Jornal Hoje”, "Bom Dia Brasil” e "Jornal da Globo", pode-se ter acesso aos arquivos das matérias dos quatro telejornais nacionais no Portal Globo.com, espaço a assinantes. Desse conteúdo foram excluídas apenas as "escaladas" das edições e as matérias que abordavam o Ano Novo, com atenção aos conteúdos que abordavam o Natal, mencionados nas sínteses de cada vídeo de arquivo. Em princípio, não foram computados a presença diária da "Previsão do Tempo", mas em muitos casos essa sessão anunciava "fortes chuvas" ou períodos de estiagem. Consequentemente, o material foi analisado, mas não contabilizado para a contagem final. Os resultados, mais do que dados quantitativos - desde o começo relativizados - foi contabilizado por telejornal, de forma a permitir uma visualização dos resultados conforme Tabela 2:

Tabela 2 - Matérias sobre o Natal, viagens, consumo e correlatos Telejornais $2013 \quad$ Telejornais 2014

\begin{tabular}{|ccc|}
\hline Bom Dia Brasil & 44 & 39 \\
\hline Jornal Hoje & 46 & 41 \\
\hline Jornal Nacional & 44 & 46 \\
\hline Jornal da Globo & 29 & 10 \\
\hline
\end{tabular}

Fonte: Dados obtidos pelas autoras.

No total de matérias sobre o Natal foram analisadas 163 matérias em 2013 e 146 matérias em 2014, posteriormente classificadas, segundo Tuchman (2002), além das seguintes subcategorias: comemoração (cobertura sobre a comemoração no mundo e no Brasil), decoração (luzes, presépios, árvores e mesas de Natal), religiosidade (assistencialismo, solidariedade), serviço (orientações sobre trânsito, compras, dicas de alimentos etc). A maior parte das matérias analisadas sobre a pauta Natal no $J N$, em dezembro de 2013 e 2014, está relacionada ao consumo. Como destaque - ou exceção a regra - chama a atenção à quantidade de matérias relacionadas à religiosidade/solidariedade no Jornal Nacional de 2014, que correspondendo a $9,5 \%$ das edições analisadas em dezembro, e quase $60 \%$ do total geral das matérias analisadas sobre o tema. Outros subtemas estão presentes nas matérias dos quatro 
telejornais, como comemoração $(6,6 \%)$, decoração $(15,3 \%)$ e curiosidade/acidentes, que correspondem a quase $11 \%$.

A distribuição do material, como é visível, privilegia as questões relativas as festas e os aspectos ligados ao consumo, apresentado como item necessário as comemorações. Esse consumo, evidentemente, vai além do ato de presentear, pois incluem aspectos relativos a decoração das festas, receitas, como arrumar as malas para a viagem, etc. De fato, muitas vezes a questão do consumo - como no caso de arrumar as malas para a viagem no final do ano, não está explícita, mas evocada de forma indireta na proposta da viagem ou da comemoração.

Grande parte do material sobre o Natal envolve também questões relativas à prestação de serviço. Conjugada ao consumo torna-se relevante não apenas o ato de consumir, mas consumir bem - com qualidade e economia. De uma maneira geral, o material que se enquadra nesta categoria foi distribuído por todo o mês de dezembro, mas com evidente crescimento numérico no final do mês. É particularmente digno de destaque o fato de que dezembro de 2013 foi o período do mês no qual se registrou as grandes tragédias climáticas no Brasil, em uma situação que (segundo o material veiculado pela própria emissora) culminou 22 mortes em Minas Gerais, 25 no Espírito Santo, além de 2 mortos no Rio e 2 mortos em São Paulo ${ }^{17}$. Embora as tragédias tenham ocorrido em diferentes datas do mês, aparentemente eram tragédias esperadas pela emissora, que já disponibiliza para seus repórteres capa de chuva e botas de borracha. Seguindo o padrão da Rede, foram feitas entrevistas, ouvidos moradores e autoridades, mas afastando as peculiaridades locais, as coberturas não afetaram a euforia natalina. Transparecia nas ações dos repórteres e dos noticiaristas - e de certa forma, até mesmo nas entrevistas editadas - uma certa burocratização das enchentes, que foram tratadas como uma pauta (mas não espetacular, ou mesmo surpreendente) comum do final de ano.

Colocadas em contraponto com o Natal de 2014, no qual o tema de maior destaque foi a ausência de chuvas, as enchentes burocratizadas (desglamurizadas) de 2014, embora centrado em matérias factuais, não apenas contabilizaram um menor número de matérias, mas sobretudo foram colocadas em um plano menor. Comparativamente também, é significativo que as chuvas de 2013, cuja maior parte da cobertura ocorreu por meio de matérias sequenciais (ver tabela TUCHMAN, 2002, pg. 9), tenham gerado a quase total ausência de serviços agregados (orientações para as vítimas e para pessoas que buscassem contato com parentes nas áreas atingidas, por exemplo), enquanto a seca no sudeste foi prolífera em matérias e dicas sobre

\footnotetext{
${ }^{17}$ Os números citados correspondem aos maiores números divulgados pela emissora, mas foi impossível fazer uma somatória exata já que muitas edições falavam em "mais uma morte confirmada"
}

Comun. \& Inf., Goiânia, GO, v. 19, n. 01, p.52-69, jan./jun. 2016 
como poupar/reaproveitar a água.

No conjunto do material analisado sobre o clima em 2013, em si mesmo deficiente, chama a atenção à valorização que foi dada as perdas materiais. Em 2014, principalmente em função do tipo de problema climático, o foco muda, deslocando-se das perdas imediatas para possíveis perdas futuras. É interessante anotar que neste ponto que a tragédia e o Natal confluem, nos comentários sobre a tristeza de enfrentar um drama que, mais do que outra coisa, é transtorno para as festas, pode atrapalhar as comemorações.

Próximas e distantes, em contrapartida, a cobertura das festas chama atenção pela alegria e pelo apelo emocional. O modelo geral é de glamurização, da festa, dos astros que irão participar, dos fogos, da decoração. Tudo é grandioso e emocional. Mesmo os congestionamentos gigantescos são prova de que a festa é importante, e todos querem participar.

Ainda analisando a relação Natal, religiosidade e consumo, é importante anotar que, segundo a Rede Globo de Televisão, os anos de 2013 e 2014 não foram bons para a economia brasileira. De uma forma geral, são constantemente anunciados os indicadores negativos, em geral comparando-os com anos anteriores. Devem ser considerados os interesses da própria Rede, cuja posição política - conforme demostrado em outras ocasiões - tende para críticas ao atual governo. No entanto, a análise do material, e especialmente as matérias de 2014 o tema consumo direto supera o material voltado para a prestação de serviço (no qual o consumo pode estar presente de forma indireta, uma vez que apresentação de uma receita envolve subjetivamente a compra dos ingredientes, e assim por diante). Esse aspecto mostra claramente a posição contraditória na qual se encontra o telejornalismo da Rede Globo. Há um claro interesse na motivação para o consumo, ele é apontado como um momento de alegria, uma premiação ao trabalho. Mas como incentivar o consumo quando a economia vai mal?

Inseridas neste contexto, as matérias sobre o consumo primaram pela contradição, transpõem-se para os shoppings lotados e para o crescimento do consumo a alegria do Natal, mas ao mesmo tempo a festa é maculada pela decepção, pela necessidade de gastar menos, de conviver as previsões negativas para o próximo ano.

Repetindo um modelo histórico, as coberturas estiveram mais centradas no eixo RioSão Paulo, locais responsáveis pelas maiores festas, mas também pelas imagens hegemônicas das grandes concentrações de pessoas, maiores engarrafamentos, pelas rodoviárias lotadas, aeroportos cheios, etc. Apesar disso, observa-se tanto em 2013 quanto em 2014 tentativas pontuais de dar destaque a algumas regiões do Brasil, como Rio Grande do Sul, Minas e alguns estados do Nordeste, além de referência a cidades de outros países, como Londres e Nova

Comun. \& Inf., Goiânia, GO, v. 19, n. 01, p.52-69, jan./jun. 2016 


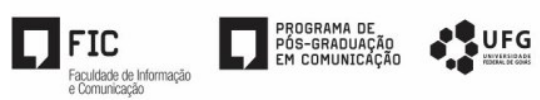

Iorque.

Igualmente notável é a pouca presença de informações com caráter de serviços no conjunto das matérias sobre as festas. As poucas exceções enfocavam o que fazer depois, em geral focando-se nos direitos do consumidor. Alternativas para os usuários, como horários das celebrações, eventos especiais ou até críticas sobre falta de alternativas, não fizeram parte do material.

\section{OHH, OHH, FELIZ NATAL E APROVEITE A FESTA, DIZ A VELHA SENHORA}

Em 2014 a Rede Globo completou 60 anos. Embora os estudiosos entendam que a Rede somente se forma dois anos mais tarde, com a compra da TV Paulista (que viria a ser a Globo São Paulo), é possível pensar que o telejornalismo da emissora é uma velha senhora que, as portas dos 60 anos, já não está na sua melhor forma, e parece presa a um padrão de dar "mais do mesmo" repetidas vezes.

Neste sentido, algumas considerações são necessárias. Primeiro a produção da televisão tem dois objetivos: informar e divertir (DUARTE, 2004, p.243), o que também influencia o telejornalismo. Cada matéria é tratada como uma unidade e valorizada em função das cenas e das informações novas. Como consequência, o telejornalismo da emissora tornouse uma colagem de conteúdos e de intenções.

Aparentemente novo, o telejornal é velho, pois se prende as temáticas recorrentes. Neste sentido, as pautas de Natal são tão previsíveis quanto a recorrência das tragédias climáticas. Ao mesmo tempo em que repete-se a imagem do Papai Noel substituindo o menino Jesus e os shoppings substituindo os presépios, também repetem-se, com novos atores, as histórias de interesse humano com foco no assistencialismo e solidariedade, trunfos sempre usados para emocionar. As práticas que abordam o tema religioso com um enfoque assistencialista também são invenções sobre o mesmo: a narrativa dramática resinificando o Natal como momento furtivo de solidariedade e de amor ao próximo. Em se tratando de Natal, o agendamento garante o conteúdo da cobertura, confirmando a dependência da pauta do telejornalismo ao previsível, e obedecendo rigorosamente a estética do entretenimento e do serviço, para fins de consumo.

Nesse sentido, aliás, o telejornalismo da Rede Globo parece contrariar a própria essência do jornalismo: a busca do novo, do imprevisível. Acostumados a liderança e a sofisticação técnica-tecnológica, vista principalmente como instrumento para excelência, o telejornalismo da Rede Globo não buscou o novo, mas antes acomodou-se a fazer melhor (ou 
com mais recursos técnicos) o que sempre fez. Mesmo anunciando (e incentivando o consumo) tecnologias nos telejornais, o telejornalismo não percebeu que a tecnologia muda comportamentos e expectativas do telespectador, que igualmente parece já responder (com audiência) as imagens repetitivas dos shoppings decorados em vermelho e verde.

Além de colocar a questão da religiosidade como um aspecto secundário, o telejornalismo da emissora também desrespeita as regras básicas do jornalismo, transformando o Natal em uma espécie de aval para desprezar/secundarizar o factual, a matéria de impacto. A emissora parece não perceber que é justamente no potencial emocional (tanto na cobertura dos fatos quanto na cobertura das Festas Natalinas) que reside o potencial do telejornalismo na televisão.

A crise de audiência da Rede Globo de Televisão, no Natal ou fora dele, deve ser vista também como uma crise produtiva-criativa do próprio telejornalismo da emissora. Evidentemente, tudo deve ser colocado no contexto, novas tecnologias e novas mídias certamente vão continuar seduzindo parte da audiência da emissora, mas também isso deve ser colocado em perspectiva, como uma chance para os responsáveis se convencerem de que o público sabe que o shopping está cheio porque os amigos já mandaram fotos, twittes e mensagens com as novidades. Como reflexão final, fica claro que ou a televisão muda o seu conteúdo, e muda igualmente o tratamento dado a esse conteúdo, inclusive se inserindo em uma relação transmidiática, no qual seja possível a inserção de um jornalismo mais interativo, mais responsável e mais multifacetado; ou irá crescer a tendência da audiência de buscar outros espaços

\section{REFERENCIAS}

BOURDIEU, P. Sobre televisão: seguido de a influência do jornalismo e jogos olímpicos. Rio de Janeiro: Jorge Zahar, 1997.

CHAPARRO, M. C. Pragmática do jornalismo: buscas práticas para uma teoria da ação jornalística. São Paulo: Summus, 1994.

CONGRESSO NACIONAL DA INTERCOM, 2010, São Paulo. Anais... São Paulo: Intercom,2010. Disponível em:<

http://www.portcom.intercom.org.br/ebooks/arquivos/03026c9bb67360675de39381ddbde65e.pdf $>$. Acesso em: 25 jan. 2015.

DIEZHANDINO, M. P. Periodismo de Servicio: La utilidad como complemento informativo en Time, Newsweek U.S. News na Woldreport y unos apontes del caso español. [s. 1.]: Icaria Editorial, 1994. (Colección Bosh Comunicación).

DUARTE, E. B. Televisão: ensaios metodológicos. Porto Alegre, RS: Sulina, 2004.

Comun. \& Inf., Goiânia, GO, v. 19, n. 01, p.52-69, jan./jun. 2016 
EIDE, M. A new kind of newspaper?understanding a popularization process. Media, culture and society: London: Thousand Oaks and New Delhi: Sage Publications, v. 1, n.19, p. 173-182, 1997.

HÁ 50 anos era inaugurada a TV Brasileira. Estadão, São Paulo, 2000. Cultura. Disponível em: $<$ http://cultura.estadao.com.br/noticias/geral,ha-50-anos-era-inaugurada-a-tvbrasileira,20000702p4944>. Acesso em: 5 jun. 2015.

JORNAL Nacional marca pior média de audiência da sua história prévia. Folha de São Paulo, São Paulo, 2014. F5. Televisão. Disponível em: <http://f5.folha.uol.com.br/televisao/2014/04/1439663jornal-nacional-marca-pior-media-de-audiencia-de-sua-historia-na-previa.shtml $>$. Acesso em: 19 maio 2015.

BLACK, N. Vigilância: a mídia mal fala de Jesus na cobertura do Natal. Folha Gospel, São Paulo, 2010. Disponível em: <http://portugues.christianpost.com/news/guardiao-a-midia-mal-fala-de-jesusna-cobertura-do-natal-1168/>. Acesso em: 02 jun. 2015.

FONSECA JÚNIOR, W. C. Análise de Conteúdo. In DUARTE, J.; BARROS, A. (Orgs.). Métodos e técnicas de pesquisa em comunicação. 2.ed. São Paulo: Atlas, 2006.

GIDDENS, A. As consequências da modernidade. São Paulo: Unesp, 1991.

GROTH, O. O poder cultural desconhecido: fundamentos das ciências dos jornais. Petrópolis: Vozes, 2011.

LOZANO, J. C. Hacia la recosideración del análisis de contenido em la investigacion de los mensajes comunicacionales. In: RUIZ, E. S.; BARBA, C. C. (Org.). Investigar la comunicación: propuestas ibero-americanas. Guadalajara: Universidad de Guadalajara/Alaic, 1994. p.135-157 .

MARCONDES FILHO, C. Comunicação e jornalismo: a saga dos cães perdidos. São Paulo: Hacker, 2000 .

MASUTTI, V. "Jornal Nacional" perde um terço de sua audiência em dez anos. Folha de São Paulo, São Paulo, 2013. F5. "Disponível em

$<$ http://f5.folha.uol.com.br/colunistas/vivianmasutti/2013/12/1384425-cai-audiencia-do-jornalnacional-e-poeta-tem-saia-justa.shtml >. Acesso em: 04 jan. 2014.

MELO, J. M. As imagens do Natal na mídia paulistana. In: MELO, J. M.; KUNSCH, W. L. De Belém a Bagé: imagens midiáticas do Natal brasileiro. São Bernardo do Campo: Universidade Metodista de São Paulo: Cátedra Unesco/UMESP de Comunicação para o Desenvolvimento Regional, 1998. p. 1726.

PENA, F. Teoria do jornalismo. São Paulo; Contexto, 2005.

MILHARES participam da Marcha para Jesus 2015 em São Paulo. Portal G1, São Paulo, 2015. Disponível em: <http://g1.globo.com/sao-paulo/noticia/2015/06/milhares-participam-da-marcha-parajesus-2015-em-sao-paulo.html>. Acesso em: 10 jun. 2015.

A MEMÓRIA do Brasil preservada. Rede Tupi de Televisão, [s.1], 2010. Disponível em: $<$ http://redetupitv.blogspot.com.br/>. Acesso em: 5 de jun. 2015.

REZENDE, G. J. Perfil editorial do telejornalismo brasileiro. São Bernardo do Campo: Unesp, 1997. 
TEMER, A. C. R. P. (Coord.) Espiando a notícia: a recepção do Jornal Nacional pelos jovens estudantes de Jornalismo. In: CONGRESSO NACIONAL DA INTERCOM, 2010, São Paulo. Anais... São Paulo: Intercom, 2010. Disponível em:< http://www.portcom.intercom.org.br/ebooks/arquivos/03026c9bb67360675de39381ddbde65e.pdf>. Acesso em: 22 jan. 2015.

TEMER. A. C. R. P. Notícias \& Serviços nos telejornais da Rede Globo. Comunicação \& Sociedade, Rio de Janeiro, v. 1, n. 37, 2002. Disponível em:

$<$ http://200.144.189.42/ojs/index.php/cs_umesp/article/view/135/3385>. Acesso em: 25 jan. 2015.

TEMER, A. C. R. P. ; TONDATO, M. P. . A televisão em busca da interatividade - uma análise dos gêneros não ficcionais. Brasília: Casa das Musas, 2009. v. 01

TEMER. A. C. R. P. Notícias \& Serviços nos telejornais da Rede Globo. Comunicação \& Sociedade, Rio de Janeiro, v. 1, n. 37, 2002. Disponível em: <

http://200.144.189.42/ojs/index.php/cs_umesp/article/view/135/3385>. Acesso em: 25 jan. 2015.

TUCHMAN, G. As notícias como uma realidade construída. In ESTEVES, J.P. Comunicação e Sociedade. Lisboa: Livros Horizontes, 2002. p. 94-104.

WEBER, M. O conceito de casta. In IANNI, O. (Org.). Teorias da estratificação social: leituras de sociologia. São Paulo: Editora Nacional, 1972. p. 136-163.

Recebido em: 29/06/2015

Aceito em: 12/10/2015

Publicado em: 11/10/2016 